\title{
Pengaruh Pembelajaran Model PAT-UT 1 dengan Bantuan Laboratorium Mini Terhadap Hasil Belajar Matematika Siswa
}

\author{
Azizah Mujahidah Annisa ${ }^{1}$, Iin Ariyanti ${ }^{2}$, Nurhaeda Patahuddin ${ }^{3}$ \\ ${ }^{1}$ Program Studi Pendidikan Matematika, Fakultas Keguruan dan Ilmu Pendidikan, Universitas Terbuka, \\ Jl. Woltermonginsidi, Lateri, Ambon, 97231 \\ ${ }^{2}$ Program Studi Pendidikan Matematika, Fakultas Keguruan dan Ilmu Pendidikan, Universitas Muhammadiyah Banjarmasin, \\ Jl. Gubernur Syarkawi, Handil Bakti, Kalimantan Selatan, 70126 \\ ${ }^{3}$ Program Studi Pendidikan Matematika, Fakultas Keguruan dan Ilmu Pendidikan, Universitas Muhammadiyah Pare Pare, \\ Jl. Jend. Ahmad Yani Km. 6, Bukit Harapan, Kecamatan Soreang, Kota Parepare, Sulawesi selatan, 91112 \\ azizah.annisa@ecampus.ut.ac.id
}

\begin{abstract}
This study aims to see the effect of the PAT-UT 1 Learning Model with the help of a Mini Laboratory which is applied to students in schools as an effort to improve mathematics learning outcomes. This is based on the fact that the UNBK results for the last 3 years as well as the TIMSS results in the Mathematics and Natural Sciences field in Indonesia are in the low category. So, it is necessary for students to get the mastery of concepts in geometry by implementing cooperative learning with the Model Tutorial Program Akreditasi Tutor Universitas Terbuka (PAT-UT 1). This study was categorized as a pre-experimental study with a one-group pretest-posttest design.The subjects of this study were students of class VIII who were taken randomly from one of the junior high schools. Data in the form of test results obtained were then analyzed using paired T-test which was first carried out by the normality test. Based on descriptive statistical analysis, the average value of mathematics learning outcomes before learning using the PAT-UT 1 Model with the help of a Mini Laboratory is 59.73 and the average value of mathematics learning outcomes after learning using the PAT-UT 1 Model with the help of a Mini Laboratory that is 82.67 . Based on inferential statistical analysis using paired t-test, a significant value is obtained $\mathrm{p}=0,000<\alpha=0,05$, this means that $\mathrm{H}_{0}$ is rejected and $\mathrm{H} 1$ is accepted. So, it can be concluded that the use of the PAT-UT 1 Model with the help of a Mini Laboratory has a positive effect on student mathematics learning outcomes.
\end{abstract}

Keywords: PAT-UT 1 Model, Mini Laboratory, learning outcomes

\begin{abstract}
Abstrak
Penelitian ini bertujuan untuk melihat pengaruh Pembelajaran Model PAT-UT 1 dengan bantuan Laboratorium Mini yang diterapkan pada siswa di sekolah sebagai upaya untuk meningkatkan hasil belajar matematika. Hal ini didasarkan pada fakta bahwa hasil UNBK 3 tahun terakhir serta hasil TIMSS bidang Matematika dan IPA Indonesia berada pada kategori rendah. Maka perlunya penanaman konsep siswa pada materi geometri dengan menerapkan pembelajaran kooperatif dengan variasi Model Tutorial Program Akreditasi Tutor Universitas Terbuka (PAT-UT 1). Penelitian ini dikategorikan sebagai penelitian pre eksperimen dengan desain penelitian one group pretest-postest design. Subjek penelitian ini adalah siswa kelas VIII yang diambil secara acak dari salah satu Sekolah Menengah Pertama. Data berupa hasil tes yang diperoleh kemudian dianalisis menggunakan Uji-T berpasangan yang terlebih dahulu dilakukan uji normalitas. Berdasarkan analisis statistik deskriptif diperoleh nilai rata-rata hasil belajar matematika sebelum pembelajaran dengan menggunakan Model PAT-UT 1 dengan bantuan Laboratorium Mini yaitu 59,73 dan nilai rata-rata hasil belajar matematika setelah pembelajaran dengan menggunakan Model PAT-UT 1 dengan bantuan Laboratorium Mini yaitu 82,67. Berdasarkan analisis statistik Inferensial menggunakan uji-t berpasangan diperoleh nilai signifikan $\mathrm{p}=0,000<\alpha=0,05$ hal ini berarti $\mathrm{H}_{0}$ ditolak dan $\mathrm{H}_{1}$ diterima. Jadi dapat disimpulkan bahwa penggunaan Model PAT-UT 1 dengan bantuan Laboratorium Mini berpengaruh positif terhadap hasil belajar matematika siswa.
\end{abstract}

Kata kunci: Model PAT-UT 1, Laboratorium Mini, Hasil Belajar

Copyright (c) 2021 Azizah Mujahidah Annisa, Iin Ariyanti, Nurhaeda Patahuddin

$\triangle$ Corresponding author: Iin Ariyanti

Email Address: iin.ariyanti1105@gmail.com (Jl. Gubernur Syarkawi, Handil Bakti, Kalimantan Selatan, 70126)

Received 19 Maret 2021, Accepted 31 Maret 2021, Published 31 Maret 2021

\section{PENDAHULUAN}

Matematika salah satu mata pelajaran yang sering menjadi pusat perhatian dalam dunia pendidikan. Pentingnya matematika juga sangat banyak dikemukakan para ahli Sebagaimana 
disampaikan bahwa "mathematics maintains an enviable position and shall continue to remain so in our everyday life. No wonder it remains as a core subject on the curricular from kindergarten to the university" (Nyikahadzoyi et al., 2013).

Namun demikian, pentingnya matematika tidak diikuti dengan mulusnya pembelajaran matematika di sekolah. Kusmaryono (2014) menjelaskan bahwa there are still a lot of students have learning difficulties and obstacles in mathematics learning both practical and emotional problems. Pendapat tersebut seolah mendukung data dari nilai matematika siswa disekolah (Kusmaryono, 2014). Data hasil belajar matematika masih sangat rendah dilihat dari capaian rerata nilai Ujian Nasional $\begin{array}{llllll}\text { Berbasis } & \text { Komputer } & \text { (UNBK) } & 3 & \text { tahun terakhir. Melalui haman }\end{array}$ https://hasilun.puspendik.kemdikbud.go.id dan https://databoks.katadata.co.id/ untuk jenjang SMPMTs, SMA-MA, dan SMK per tanggal 28 Juli 2019 memberikan data bahwa matematika menjadi mata pelajaran dengan nilai terendah dibandingkan tiga mata pelajaran lain yang diujiankan.

Selain itu, hasil studi internasional dalam bidang Matematika dan IPA TIMSS mengemukakan bahwa prestasi siswa Indonesia berada jauh di bawah rata-rata internasional (Desmayanasari et al., 2018). Pada studi tersebut, materi yang diujikan salah satunya adalah domain geometri yakni soal materi bangun ruang sisi datar. Umumnya siswa Indonesia tidak berhasil menjawab dengan benar. Sebagai contoh soal berikut:

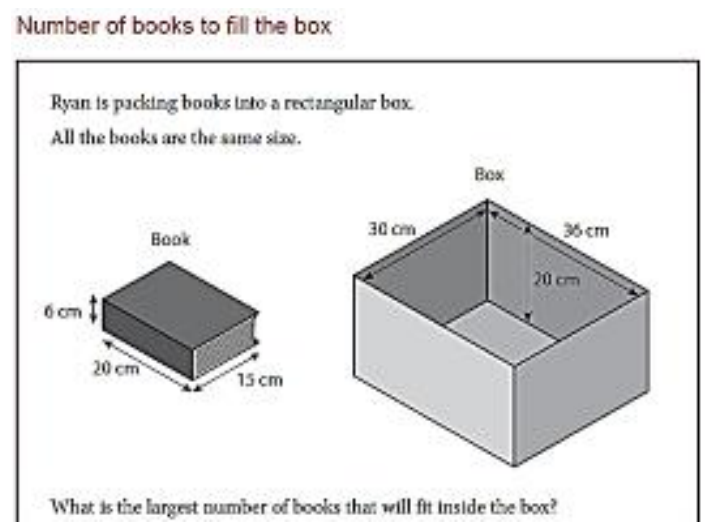

Gambar 1 Soal Bangun Ruang Sisi Datar TIMMS 2013 (Desmayanasari et al., 2018)

Gambar 1 di atas menunjukkan hanya sekitar $11 \%$ siswa Indonesia yang memberi jawaban benar dari rerata Internasional sekitar 25\%. Hasil tersebut menunjukkan masih rendahnya pemahaman siswa Indonesia tentang materi bangun ruang sisi datar (Desmayanasari et al., 2018). Fakta tersebut patut menjadi perhatian beragai pihak. Beberapa upaya yang telah dan dapat dilakukan untuk meningkatkan hasil belajar matematika. Salah satunya dengan penggunaan model pembelajaran yang sesuai. Sebagaimana disebutkan bahwa penerapan model pembelajaran menjadi salah satu faktor utama dalam proses pembelajaran (Risna Dewi Aryanti, 2015).

Penulis melihat salah satu upaya untuk menanamkan pemahaman konsep pada materi geometri adalah dengan menerapkan pembelajaran kooperatif, yaitu dengan variasi pembelajaran Model Tutorial Program Akreditasi Tutor Universitas Terbuka atau disingkat sebagai PAT-UT 1. Model Pembelajaran 
PAT-UT ini merupakan Model Tutorial yang dikembangkan Universitas Terbuka yang bertitik tolak dari belajar mandiri dalam pencapaian kompetensi yang kemudian di desain menjadi sebuah model pembelajaran. Saat ini penelitian yang menggunakan Model PAT-UT cukup terbatas, yang penulis temui antara lain penelitian Patmawati (2010) dan Fadloli (2011). Patmawati, (2010) dalam penelitiannya menerapkan model PAT-UT II, hasil yang diperoleh menunjukkan bahwa ada peningkatan keaktifan, motivasi, dan pemahaman mahasiswa yang diajar dengan menggunakan Model PAT-UT II. Walaupun sering diterapkan bagi mahassiwa dalam ranah tutorial namun pembelajaran ini tentu dapat juga diterapkan di jenjang Pendidikan menengah ke atas (Patmawati, 2010). Ehly dan Larsen (dalam Fadloli, 2011) menyatakan bahwa "siswa atau murid yang diajar melalui kegiatan tutorial akan lebih mampu menguasai bahan/materi yang disampaikan karena ia dapat belajar melalui proses mengkaji atau menelaah, bukan menghafal sehingga sesorang lebih mampu berkomunikasi dengan orang lain”. Penelitian lain dari Fadloli (2011) yang membandingkan antara penggunaan Model PAT-UT 1 dengan Model STAD (Student Team Achievement Devision) yang menuliskan bahwa penggunaan Model STAD lebih baik dibandingkan PAT-UT 1 namun dilanjutkan dengan beberapa penyebab yang menuliskan bahwa hasil penelitian tersebut bias (Fadloli, 2011).

Pada Pembelajaran Model PAT-UT 1 yang digunakan pada penelitian ini, guru tetap akan memberikan informasi kepada siswa satu arah namun yang membedakan adalah setelah guru menerangkan siswa diminta untuk berdiskusi dengan membentuk kelompok kecil. Diskusi kelompok kecil tersebut akan melatih siswa terlibat secara aktif dalam memperoleh informasi dan memahami konsep matematika. Hal ini sejalan dengan pendapat (Gull \& Shehzad, 2015) yang menjelaskan hasil penelitiannya bahwa kegiatan pembelajaran kooperatif memiliki efek positif pada prestasi akademik siswa. Pada konteks perkuliahan, program tutorial memfasilitasi mahasiswa dalam berdiskusi secara intensif antara tutor dengan mahasiswa maupun antarmahasiswa tentang isi atau materi yang sedang dipelajari sehingga dapat melakukan internalisasi terkait materi maupun isi dari program perkuliahan (Muzammil et al., 2012). Oleh karena itu, dalam pembelajaran di sekolah terhadap siswa juga diharapkan memberikan efek yang serupa.

Geometri merupakan materi pelajaran yang memerlukan aktivitas penggunaan benda-benda konkrit sehingga jika hanya diskusi kelompok kecil tentu kurang lengkap dalam memfasilitasi siswa memahami domain geometri maka dari itu penulis menambahkan penggunaan laboratorium mini dalam proses belajar kelompok. Hal ini sesuai dengan Teori Konstruktifisme Bruner yang menjelaskan agar siswa diarahkan untuk berpartisipasi aktif dalam memperoleh pengalaman serta bereksperimen untuk memahami ataupun menemukan berbagai prinsip dan konsep-konsep pembelajaran (Trianto, 2011).

Dengan demikian dalam kegiatan laboratorium mini siswa dituntut harus mampu memperagakan alat dalam mengkonstruksi konsep maupun prinsip yang dipelajari. Di dalam kelas, memungkinkan terdapat beberapa siswa yang tidak mampu melaksanakan kegiatan laboratorium mini dengan baik, mengingat kemampuan siswa yang heterogen, maka dengan pertimbangan keadaan tersebut metode laboratorium mini dipandang lebih tepat jika dipadukan dengan pembelajaran PAT-UT1 yang 
didalamnya memuat pembelajaran kooperatif. Berdasarkan uraian yang dikemukakan di atas, maka penulis berkeinginan untuk mengadakan sebuah penelitian dengan judul "Pengaruh Pembelajaran Model PAT-UT 1 dengan Bantuan Laboratorium Mini Terhadap Hasil Belajar Matematika Siswa". Peneliti berharap penelitian ini dapat menjadi referensi dan bahan pertimbangan perbaikan proses pembelajaran matematika di sekolah khususnya pada jenjang Sekolah Menengah Pertama.

\section{METODE}

Metode penelitian yang digunakan oleh penulis dikategorikan dalam penelitian eksperimen dengan pendekatan kuantitatif. Jenis penelitian ini adalah Pre-experimental dengan desain penelitian one-group pretes-posttest design.

Tabel 1. Desain Penelitian

\begin{tabular}{|c|c|c|}
\hline Pretest & Treatment & Posttest \\
\hline $\mathrm{O}_{1}$ & $\mathrm{X}$ & $\mathrm{O}_{2}$ \\
\hline
\end{tabular}

Sumber: (Sugiyono, 2015)

Penelitian berupa implementasi Pembelajaran Model PAT-UT 1 dengan bantuan laboratorium mini di salah satu SMP di Makassar. Penelitian awal berlangsung sejak 30 Oktober 2019 sampai November 2019 dengan subjek penelitian siswa kelas VIII terdiri dari 31 siswa yang dipilih dengan menggunakan teknik cluster random sampling.

Hipotesis penelitian dalam penelitian ini adalah: "ada pengaruh positif pembelajaran model PATUT dengan bantuan laboratorium mini terhadap hasil belajar matematika siswa”. Untuk pengujian hipotesis, maka hipotesis statistik dirumuskan sebagai berikut:

$$
\mathrm{H}_{0}: \mu_{B}=0 \text { lawan } \mathrm{H}_{1}: \mu_{B}>0
$$

$\mathrm{H}_{0}$ : tidak ada pengaruh positif yang signifikan pembelajaran model PAT-UT 1 dengan bantuan laboratorium mini terhadap hasil belajar matematika siswa.

$\mathrm{H}_{1}$ : ada pengaruh positif yang signifikan pembelajaran model PAT-UT 1 dengan bantuan laboratorium mini terhadap hasil belajar matematika pada siswa.

$\mu_{B}$ : Rata-rata nilai selisih antara Pretest dan Posttest siswa.

$\mu_{1}$ : nilai rata-rata hasil belajar matematika pada siswa sebelum pembelajaran model PAT-UT 1 dengan bantuan laboratorium mini (nilai rata-rata Pretest).

$\mu_{2}$ : nilai rata-rata hasil belajar matematika pada siswa setelah pembelajaran model PAT-UT 1 dengan bantuan laboratorium mini (nilai rata-rata Posttest)

Catatan: pembelajaran model PAT-UT1 dengan bantuan laboratorium mini dikatakan berpengaruh terhadap hasil belajar matematika apabila terjadi peningkatan yang signifikan dari hasil pretest dan postest.

Data yang dikumpulkan dalam penelitian ini antara lain 1) data tentang learning obstacle yang dihadapi siswa dalam mempelajari materi garis dan sudut, data ini diperoleh dari hasil studi pendahuluan 
yang dilakukan dan analisis penelitian sebelumnya, 2) kedua data tentang materi garis dan sudut dilihat dari perspektif teoretis, diperoleh dari analisis secara teoritis dan kajian repersonalisasi peneliti, 3) data hasil implementasi desain didaktis, diperoleh melalui observasi selama implementasi desain didaktis.

Teknik pengumpulan data dalam penelitian ini adalah teknik tes, data mengenai hasil belajar matematika ditinjau dari aspek kognitif siswa dikumpulkan dengan memberikan tes kepada siswa sebelum (pretest) dan setelah (postest) adanya perlakuan.

Analisis data dalam penelitian ini terbagi atas dua yaitu analisis deskriptif dan analisis statistik inferensial. Analisis statistik deskriptif meliputi: skor tertinggi, skor terendah, skor rata-rata, standar deviasi, distribusi frekuensi, dan distribusi persentase. Sedangkan untuk analisis statistik inferensial data dianalisis dengan menggunakan uji-t berpasangan tetapi terlebih dahulu data tersebut di analisis dengan menggunakan uji normalitas.

\section{HASIL DAN DISKUSI}

\section{Hasil Validasi Perangkat Pembelajaran dan Instrumen}

Validasi ini dilakukan untuk memeriksa isi (content), konstruksi (construct), dan keterbacaan atau bahasa (face) suatu instrumen. Perangkat pembelajaran dan Instrumen yang dimaksud adalah (1) Rencana Pelaksanaan Pembelajaran (RPP), (2) Lembar Kegiatan Siswa (LKS), dan (3) Instrumen Tes. Penilaian Ahli atau Pakar berupa pemberian skor pada aspek yang dinilai dan memberikan catatan pada bagian yang perlu dilakukan revisi. Pada proses validasi ini juga dilakukan pembimbingan guna untuk memperbaiki perangkat dan instrumen yang dirancang peneliti. Pada penelitian ini digunakan 3 validator yaitu pakar matematika, pakar Model Pembelajaran PAT-UT, dan guru matematika.

Berdasarkan hasil uji validitas teoretik diperoleh nilai 4,2 untuk hasil validasi ahli pada RPP, dan 4,3 untuk LKS, serta nilai 4,5 pada instrumen tes. Nilai ini menyatakan bahwa secara teoriris perangkat pembelajaran tersebut valid yang artinya para ahli sepakat bahwa rencana pelaksanaan pembelajaran (RPP), Lembar Kegiatan Siswa (LKS), dan Instrumen Tes yang dirancang peneliti layak untuk digunakan pada penelitian.

Secara keseluruhan, hasil validasi para ahli terhadap perangkat pembelajaran dan instrumen adalah sebagai berikut:

1) Rencana Pelaksanaan Pembelajaran (RPP), Lembar Kegiatan Siswa (LKS), dan instrumen tes dinilai termasuk kategori baik dan direkomendasikan dapat digunakan dengan beberapa revisi.

2) Untuk beberapa soal pada Instrumen tes dilakukan revisi terutama penyempurnaan gambar maupun penambahan keterangan pada gambar berdasarkan saran yang disampaikan oleh para validator.

\section{Analisis Statistik Deskriptif dan Inferensial}

Analisis statistik deskriptif bertujuan untuk mendeskripsikan variasi data yang telah diperoleh melalui instrumen penelitian (hasil pretest dan postest) yang diajar menggunakan Pembelajaran Model PAT-UT 1. Analisis statistik deskriptif menggunakan media SPSS (Statistical Product and Service Solutions) versi 25 yang dipaparkan berikut ini. 
Pengaruh Pembelajaran Model PAT-UT 1 dengan Bantuan Laboratorium Mini Terhadap Hasil Belajar Matematika Siswa, Azizah Mujahidah Annisa, Iin Ariyanti, Nurhaeda Patahuddin

Tabel 2. Statistik Deskriptif Hasil Pretest dan Posttest

\begin{tabular}{|c|c|c|c|}
\hline & Pretest & Postest \\
\hline \multirow[t]{2}{*}{$\mathrm{N}$} & Valid & 31 & 31 \\
\hline & Missing & 0 & 0 \\
\hline \multicolumn{2}{|c|}{ Mean } & 59.7294 & 82.6742 \\
\hline \multicolumn{2}{|c|}{ Median } & 62.9000 & 85.4800 \\
\hline \multicolumn{2}{|c|}{ Mode } & $61.29^{\mathrm{a}}$ & 100.00 \\
\hline \multicolumn{2}{|c|}{ Std. Deviation } & 15.50092 & 14.50394 \\
\hline \multicolumn{2}{|c|}{ Variance } & 240.278 & 210.364 \\
\hline \multicolumn{2}{|c|}{ Range } & 74.19 & 54.84 \\
\hline \multicolumn{2}{|c|}{ Minimum } & 14.52 & 45.16 \\
\hline \multicolumn{2}{|c|}{ Maximum } & 88.71 & 100.00 \\
\hline
\end{tabular}

Data pada Tabel 2, dapat disimpulkan bahwa hasil belajar matematika siswa sebelum pembelajaran dengan menggunakan Model PAT-UT 1 dengan bantuan laboratorium mini belum mencapai ketuntasan minimum atau masih dalam kategori rendah. Sedangkan hasil belajar matematika siswa setelah pembelajaran dengan menggunakan Model PAT-UT 1 dengan bantuan laboratorium mini telah mencapai ketuntasan minimum dan mengalmi peningkatan dari hasil pretest.

Hasil analisis statistik inferensial dipaparkan sebagai berikut:

\section{Uji Normalitas}

Berdasarkan hasil analisis data dengan menggunakan uji Kolmogrov-Smirnov Normality Test dan Shapiro-Wilk masing-masing diperoleh nilai sig $=0,200 \mathrm{dan} \operatorname{sig}=0,615$ yang dapat dilihat pada tabel 3 berikut ini.

Tabel 3. Uji Kolmogrov-Smirnov Normality Test dan Shapiro-Wilk

\begin{tabular}{|l|r|r|r|r|r|r|}
\hline \multicolumn{1}{|c|}{ Tests of Normality } \\
\hline & \multicolumn{2}{|c|}{ Kolmogorov-Smirnova } & \multicolumn{3}{c|}{ Shapiro-Wilk } \\
\cline { 2 - 7 } & Statistic & df & Sig. & Statistic & df & Sig. \\
\hline Residu & .096 & 31 & $.200^{*}$ & .973 & 31 & .615 \\
\hline *. This is a lower bound of the true significance. \\
a. Lilliefors Significance Correction \\
a.
\end{tabular}

Nilai signifikan yang diperoleh lebih besar dari nilai signifikan $\alpha=0,05(0,200>0,05)$ dan $(0,615>0,05)$ sehingga dapat disimpulkan bahwa data tersebut berdistribusi normal, jadi pengujian normalitas terpenuhi.

\section{Uji Hipotesis}

Berdasarkan hasil analisis data untuk statistik inferensial, diperoleh nilai peluang $\operatorname{sig}=0,000$ untuk $\alpha=0,05$, yang dapat dilihat pada tabel 4 berikut ini. 
Tabel 4. Uji-T Berpasangan

\begin{tabular}{|c|c|c|c|c|c|c|c|c|c|}
\hline \multicolumn{10}{|c|}{ Paired Samples Test } \\
\hline & & \multicolumn{5}{|c|}{ Paired Differences } & \multirow[b]{3}{*}{$t$} & \multirow[b]{3}{*}{$\mathrm{df}$} & \multirow[b]{3}{*}{ Sig. (2-tailed) } \\
\hline & & \multirow[b]{2}{*}{ Mean } & \multirow{2}{*}{$\begin{array}{c}\text { Std. } \\
\text { Deviation }\end{array}$} & \multirow{2}{*}{$\begin{array}{c}\text { Std. Error } \\
\text { Mean }\end{array}$} & \multicolumn{2}{|c|}{$\begin{array}{c}95 \% \text { Confidence } \\
\text { Interval of the } \\
\text { Difference }\end{array}$} & & & \\
\hline & & & & & Lower & Upper & & & \\
\hline Pair 1 & $\begin{array}{l}\text { Postest - } \\
\text { Pretest }\end{array}$ & $\begin{array}{r}22.944 \\
84\end{array}$ & 8.08337 & 1.45182 & $\begin{array}{r}19.979 \\
83\end{array}$ & 25.90984 & $\begin{array}{r}15.80 \\
4\end{array}$ & 30 & .000 \\
\hline
\end{tabular}

Secara statistik hipotesis $\mathrm{H}_{0}$ ditolak dan Hipotesis penelitian diterima. Jadi dapat disimpulkan bahwa ada pengaruh positif yang signifikan setelah menerapkan Pembelajaran Model PAT-UT 1 dengan bantuan laboratorium Mini terhadap hasil belajar matematika siswa.

\section{Pembahasan Hasil Penelitian}

Penelitian ini dilakukan selama 6 kali pertemuan, dengan tujuan untuk mengetahui pengaruh pembelajaran Model PAT-UT 1 dengan bantuan laboratorium mini terhadap hasil belajar matematika siswa. Pada prosesnya pembelajaran Model PAT-UT 1 akan digunakan untuk membantu siswa untuk memami setiap materi yang diberikan melalui serangkaian proses pembelajaran. Proses pembelajaran ini menggunakan 4 Fase yaitu Pada tahap awal pembelajaran (fase 1) guru mengorganisasikan siswa kedalam kelompok-kelompok kecil 4-5 orang secara heterogen, kemudian fase 2 diskusi kelompok, fase ke tiga yaitu Tanya silang, dimana setiap kelompok akan diberikan kesempatan untuk memberikan pertanyaan, dan ditutup dengan fase Pemantapan yang meminta siswa untuk membuat rangkuman dan kesimpulan.

Setelah dilakukan penelitian dan dilakukan analisis data menggunakan statistik deskriptif, hasilnya menunjukkan bahwa nilai rata-rata hasil belajar matematika peserta siswa sebelum pembelajaran dengan menggunakan Model PAT-UT 1 dengan bantuan laboratorium mini (pretest) adalah sebesar 59,73 dan berada pada kategori rendah. Sedangkan, nilai rata-rata hasil belajar matematika siswa setelah pembelajaran dengan menggunakan Model PAT-UT 1 dengan bantuan laboratorium mini (postest) adalah sebesar 82,67 dan berada pada kategori tinggi. Nilai rata-rata hasil belajar matematika siswa dari hasil pretest ke posttest mengalami peningkatan yang signifikan.

Pengujian hipotesis dianalisis dengan menggunakan analisis statistik inferensial. Tujuan dilakukan analisis statistik inferensial adalah untuk pengambilan keputusan mengenai ada tidaknya pengaruh positif penggunaan Model PAT-UT 1 dengan bantuan laboratorium mini terhadap hasil belajar matematika siswa. Dari hasil analisis statistik inferensial, secara statistik, hipotesis $\mathrm{H}_{0}$ ditolak dan $\mathrm{H} 1$ diterima. Sehingga dapat disimpulkan bahwa ada pengaruh positif yang signifikan penggunaan pembelajaran model PAT-UT dengan bantuan laboratorium mini terhadap hasil belajar matematika siswa.

Hasil yang diperoleh pada penelitian ini yang berfokus pada hasil belajar kognitif tingkat sekolah 
khususnya kelas VIII SMP melalui penggunaan model PAT-UT juga sejalan dengan hasil penelitian lain pada tingkat universitas. Adapun hasil penelitian tersebut diantaranya oleh Widuroyekti (2006) melalui rancangan penelitian tindakan terhadap mahasiswa bahwa hasil penerapan pendekatan belajar aktif melalui proses tutorial salah satu jenis PAT-UT selain dapat meningkatkan partisipasi juga berdampak pada peningkatan hasil belajar dari siklus I ke siklus III pada mata kuliah Pendidikan matematika (Widuroyekti, 2006).

\section{KESIMPULAN}

Berdasarakan hasil penelitian dan pembahasan diperoleh beberapa kesimpulan sebagai berikut:

1. Rata-rata hasil belajar matematika siswa sebelum pembelajaran model PAT-UT 1 dengan bantuan laboratorium mini adalah sebesar 59,73 dan berada pada kategori "rendah".

2. Rata-rata hasil belajar matematika siswa setelah pembelajaran model PAT-UT 1 dengan bantuan laboratorium mini adalah sebesar 82,67 dan berada pada kategori "tinggi".

3. Ada pengaruh positf penggunaan pembelajaran model PAT-UT 1 dengan bantuan laboratorium mini terhadap hasil belajar matematika siswa dengan taraf signifikansi.

\section{UCAPAN TERIMA KASIH}

Ucapan terima kasih dan penghargaan kepada Lembaga Penelitian dan Pengabdian kepada Masyarakat Universitas Terbuka yang telah memberikan kepercayaan, kesempatan, serta dukungan baik moril maupun materil kepada penulis mulai awal penelitian sampai publikasi hasil penelitian

\section{REFERENSI}

Desmayanasari, D., Prabawanto, S., \& Dasari, D. (2018). Peningkatan Kemampuan Bepikir Kreatif Matematis Siswa SMP dengan Pendekatan Problem Centered Learning. Hipotenusa (Journal of Mathematics Education), 1(1), 14-28.

Fadloli. (2011). TUTorial Model Program Akreditasi Tutor I (Pat-Ut) I Dan Student Team Achievement Division (STAD) Ditinjau Dari Motivasi Belajar Mahasiswa. Jurnal Pendidikan Terbuka Dan Jarak Jauh, 12(2), 133-144.

Gull, F., \& Shehzad, S. (2015). Effects of Cooperative Learning on Students' Academic Achievement. Journal of Education and Learning (EduLearn), 9(3), 246. https://doi.org/10.11591/edulearn.v9i3.2071

Kusmaryono, I. (2014). The Importance of Mathematical Power in Mathematics Learning. International Conference on Mathematics, Science, and Education, 35-40. https://doi.org/10.35534/tms.0202010c

Muzammil, M., Andayani, Mulyatno, Santosa, T., \& Rusli, Y. (2012). Evaluasi Pelatihan Akreditasi Tutor UT (PATUT). Universitas Terbuka.

Nyikahadzoyi, M. R., Mapuwei, T., \& Chinyoka, M. (2013). Some Cognitive Obstacles Faced By “A” 
Level Mathematics Students in Understanding Inequalities: A Case Study of Bindura Urban High Schools. International Journal of Academic Research in Progressive Education and Development, 2(2), 206-221.

Patmawati. (2010). Penerapan Model Tutorial Pat UT-II Dalam Pembelajaran Keterampilan Menulis Narasi Program S1 Pgsd UPBJJ-UT Makassar. Jurnal Pendidikan, 11(1), 42-49. https://doi.org/10.33830/jp.v11i1.544.2010

Risna Dewi Aryanti. (2015). Perbandingan Penerapan Model Pembelajaran Kooperatif Tipe Jigsaw Dengan Tipe Belajar Bersama (Learning Together) Pada Mata Pelajaran Konstruksi Bangunan Kelas $X$ DI SMK Negeri 9 GARUT [Universitas Pendidikan Indonesia]. http://repository.upi.edu/16005/

Sugiyono. (2015). Metode penelitian pendidikan pendekatan kuantitatif, kualitatif, dan $R \& D$. Alfabeta.

Trianto. (2011). Mendesain model pembelajaran inovatif-progresif: konsep, landasan, dan implementasinya pada Kurikulum Tingkat Satuan Pendidikan (KTSP) (Pertama). Kencana Prenada Media Group.

Widuroyekti, B. (2006). Pendekatan Belajar Aktif Dan Peningkatan Partisipasi Mahasiswa Dalam Proses Tutorial Tatap Muka. Jurnal Pendidikan, 7(1), 55-65. 